\title{
Diversification of Crops and Conservation Management in Lowland Soils of Rio Grande do Sul
}

\author{
Cristian Troyjack ${ }^{1}$, João R. Pimentel ${ }^{1}$, Vinícius J. Szareski ${ }^{1}$, Ivan R. Carvalho ${ }^{1}$, Francine Lautenchleger ${ }^{2}$, \\ Bruno de L. Vargas ${ }^{1}$, Maikel L. Habitzreuter ${ }^{1}$, Daniele B. Rodrigues ${ }^{1}$, Andrea B. N. Martins ${ }^{1}$ \\ \& Lilian V. M. de Tunes ${ }^{1}$ \\ ${ }^{1}$ Universidade Federal de Pelotas, Capão do Leão, Rio Grande do Sul, Brazil \\ ${ }^{2}$ Universidade Estadual de Maringá, Maringá, Paraná, Brazil \\ Correspondence: Ivan Ricardo Carvalho, Universidade Federal de Pelotas, Capão do Leão, Rio Grande do Sul, \\ Brazil. Tel: 55-9640-8757. E-mail: carvalho.irc@gmail.com
}

Received: October 24, 2018

Accepted: February 2, 2019

Online Published: July 31, 2019

doi:10.5539/jas.v11n12p1

URL: https://doi.org/10.5539/jas.v11n12p1

\begin{abstract}
The lowland soils in Rio Grande do Sul occupy an area of approximately 5.4 million hectares of the state. They are flat to mildly hilly topography soils, developed, under varied conditions of drainage deficiency (hydromorphism). In this ecosystem, the extensive productive livestock system and irrigated rice were developed, used successfully for many decades. However, its characteristics and peculiarities have contributed to the cost of production, disseminate weed seeds in the crops and degrade the physical state of the lowland soils, due to this, the interest arose for the use of new alternatives that were, at the same time, efficient in the control of red rice, economically viable and able to maintain or even recover soil quality. The search for practices capable of increasing the productivity of irrigated rice and, especially, its sustainability over time has been the focus of several studies, so the objective of this review was to present aspects related to crop diversification and conservation management of lowland soils, mainly in relation to rotation and succession practices.
\end{abstract}

Keywords: rotation of crops, hydromorphic soils, Zea mays, Glycine max, Oryza sativa

\section{Introduction}

The great majority of arable areas, with species of agronomic interest, in terms of drainage, have adequate soil conditions for cultivation. However, approximately $6 \%$ of the terrestrial surface is subject to temporary flooding of the soil. In Brazil, about 33 million hectares are considered as lowland and of difficult drainage soils (Pinto et al., 2006).

The lowland soils developed in Rio Grande do Sul are characterized by being hydromorphic, with a thin surface and an impermeable subsurface, generally associated with a flat or hilly topography, occupy an area of approximately 5.4 million hectares (Pinto et al., 1999), which corresponds to $20 \%$ of the area of the State. They are soils with a flat to mildly hilly surface, developed under different conditions of drainage deficiency, where due to poor drainage, the porous spaces are saturated with water, which causes a series of changes in the soil-plant dynamics (Bailey-Serres \&Voesenek, 2008).

Associated to the poor drainage aspects, the soils of lowland or hydromorphic also present, in their majority, density and micro/macropores relation naturally elevated, in addition to low storage capacity of water in the superficial layer, mainly those that have thin A superficial horizon (Meurer, 2017). These characteristics, in some cases combined with natural fertility from medium to low, make it difficult to use a diversified agriculture (Santos \& Zaroni, 2011), so under such conditions the extensive livestock production system and irrigated rice developed.

Among the soil classes included as lowland, the highlights are the Planosols that represent around $56 \%$ of the lowland areas of Rio Grande do Sul, Chernozems (16.1\%), Entisols (11.6\%), Plinthosols in which are included the Luvisols, Acrisols (8.3\%) and Gleysols (7.1\%) (Neto \& Silva, 2011). Areas with these soils are subject to periodic flooding, causing alterations in the balance of mineral elements and compounds present in the soil, triggering a series of changes in the plant metabolism and that have reflections on yield and seed quality, unlike that observed in soils with adequate drainage, as in the case of Ferralsols (Sousa \& Lobato, 2007). 


\section{Problems Associated With the Predominant Productive System in Lowland Soils}

Lowland soils naturally present physical limitations that hinder the diversification of crops in these areas, which contributes to the predominance of the successive cultivation of irrigated rice in the same area over the years. Rice coexists well with oxygen deficiency and low soil redox potential induced by flooding, but these characteristics negatively affect many aspects of plant physiology, such as carbon assimilation, macronutrient absortion, and suppression of respiratory metabolism of other species' roots (Bailey-Serres \& Colmer, 2014).

The microbial flora of soils with excess of water can also be altered, becoming progressively anaerobic. In these soils, the accumulation of $\mathrm{CO}_{2}$, ethylene, methane, several other compounds and ions resulting from the plant's own microbial anaerobic metabolism, such as ethanol, lactate, organic acids, $\mathrm{Fe}^{2+}, \mathrm{Mn}^{2+}$, and $\mathrm{S}^{2-}$, which can harm the development of plants. As a consequence of the reduction of the oxygen level there is the stomatal closure, damage to photosystem II and the decrease in photosynthesis (Mittler, 2002; Ramesh, 2009; Van Dongen et al., 2011).

On the other hand, a situation that is averse to water excess, consists of lack of water or water deficiency that present floodplain areas, mainly due to the low concentration of organic matter and the low water retention capacity during periods of water restriction (Meurer, 2017). From these findings, it is clear that the peculiar characteristics of this growing environment hinders the diversification of species and has contributed to the cost of production, which contributed to the consolidation of rice monoculture.

The increasing use of lowland soils with rice crop in the conventional system, associated to monoculture, has increased the pressure of weeds in the areas used with the crop. The pressure is evidenced in quantitative and qualitative terms, since species such as joint-vetch (Aeschynomene sp.) and cyperaceae (Cyperus sp.), which were recently considered weeds of secondary importance, mainly in relation to red rice and barn grass (Echinochloa sp.), are now problems in certain areas of Rio Grande do Sul (Kissmann, 2007; Lamego, 2009; Massa et al., 2011).

\section{Alternatives to the Conventional System of Rice Crop}

The current production system of irrigated rice in lowland soils in the state of Rio Grande do Sul, due to its different peculiarities and characteristics, has contributed to the cost of production, disseminating weed seeds in the crops and degrading the physical properties of these soils, with that, there is a demand for the use of new alternatives that are more efficient in controlling red rice and other resistant species, economically more viable and capable of maintaining or even recovering soil quality, so, among these alternatives, crop rotation stands out.

\section{Rotation and Succession of Crops in Lowland Áreas}

Crop rotation can be defined as the orderly alternation of different crops over a period of time, in the same crop, for defined purposes, and a plant species is not repeated in the same place with a shorter interval of two years and, if possible, three or more. The crop succession is conceptualized as the pre-established sequence of crops within the same agricultural year.

Crop rotation systems contribute to the sustainability of production systems. Among the main advantages are the reduction in weed infestation, disease control through cycle breaks and nutrient cycling due to the use of plant species with different root systems (Rego, 1994).

In addition to the control of red rice, crop rotation contributes to increase grain yield of irrigated rice grown in succession (Montealegre \& Vargas, 1989; Pauletto et al., 1991). Reduction of the amount of red rice seeds in the soil by crop rotation was verified by Marchezan (2013) and Avila et al. (2000), that is, the use of these crops in lowland soils cultivated with irrigated rice reduces the levels of weed infestation in rice crops, improve soil use and quality, optimize the use of machines and labor, diversify incomes, break cycles of diseases and pests and increase the profitability of the area.

The most widely used upland crops in rotation or succession with irrigated rice are maize, soybean and sorghum, as well as some cultivated pasture species. Several works have been carried out in order to make possible other crops for the lowland areas, mainly maize (Zea mays) and soybean (Glycine max). Thus, researches conducted by EmbrapaClimaTemperado in Capão do Leão, since 1986 (Gomes \& Magalhães Júnior, 2004) have sought to identify maize cultivars that are more suited to lowland soil conditions. From 1998, these works were extended to the Campanha region. Maize is a species that has in the lowland soil several characteristics capable of restricting its growth. It is fundamental to choose the cultivar that has a vigorous stem, adequate stature, low ear insertion and resistance to lodging and to breaking. 
However, rotation has shown great benefits, its use in hydromorphic soils, is still limited to few properties. Problems relating to the high sensitivity of most species cultivated to excess water in the soil, poor physical and chemical soil conditions (poor soil quality), cultural problems and, in some cases, marketing difficulties, have prevented the expansion of upland crops in lowland soils cultivated with irrigated rice (Gomes et al., 2004).

Improvements in soil quality: Soil quality is determined through its functionalities, so a given type of soil is considered of good quality when it has the capacity, within the limits of a natural or managed ecosystem, to maintain productivity and plant and animal biodiversity, improve air and water quality and allow housing and human health. For the adoption of the rotation and succession system in the lowland area for upland crops it is necessary to evaluate this quality, which is done through a visual analysis and physical, chemical and biological attributes of the soil. In the lowland areas, the most limiting factor for the implantation of maize and soybean crops is drainage, where the electrical conductivity of these soils is generally low, and the accuracy in planing and topography correction is necessary (SOSBAI, 2010).

Use of adapted materials: The use of materials that are less sensitive to excess water in the soil is essential for the implantation of these upland crops in a lowland area. For, the excess of water in the soil affects the growth and development of these species, causing morphological and physiological changes, because it reduces the level of 02 and with that the diffusion rate. The extent of these damages is variable in relation to the duration of the saturation period, stage of development, species and environmental conditions (Gomes et al., 2002), so it is necessary to use these materials more adapted to these lowland areas. In addition to the use of more adapted materials, it is possible to use efficient management for the implementation of upland crops (Vernetti \& Gomes, 2009).

Soil drainage: The realization of soil drainage is one of the main factors for the implementation of these rotation systems in lowland areas, for this it is necessary to carry out a previous study of the terrain, where it is evaluated the possibility of soil planing to correct the topography, systematizing the area, improving the surface runoff and thus soil drainage (Gomes et al., 2002). As the use of the ridge method reduces soil saturation time, promoting greater aeration to the root system of crops (Silva et al., 2007).

Soil decompression: Soil compaction occurs due to machine traffic and soil operations generate tensions forming a compacted layer on the surface, so as to limit soil physical quality (Reichart et al., 2005). In the lowland areas, it is one of the main reasons for the inefficiency of the implantation of the upland crops in these areas, since it diminishes the root development and the infiltration of water (Pauletto et al., 2004). Among the main measures to decompress these soils is scarification, which reduces soil density, microporosity, micro/macropores, and increases macroporosity and total porosity (Machado et al., 1996). Marchesan et al. (2013), when studying systems of soybean implantation in lowlands, found that the scarification provided greater root development, due to the lower resistance to penetration and lower density.

\section{Reduction of Crop Sensitivity to Excess Water in Soil}

Low yields of upland crops implanted in lowland areas due to inadequate management of these crops is the main reason for the failure of this system, where the use of inadequate materials and the need to better understand the practices in these areas limit the use of crops for the succession and rotation with the irrigated rice. However, when the correct management recommendations are respected, it is possible to produce high yields, as is the case of the soybean crop. The soybean crop is highlighted in the implementation of this system, being able to tolerate water excesses, improve fertility, reduce the weed seed bank and enable a source of income to the farmer when well managed in lowland areas (Müller, 2015).

In addition to the use of adapted materials that are obtained through the plant breeding, the correct management reduces the sensitivity of the crops to the excess of water in the soil. It is necessary to modify the physical environment of the soil and the correct management of the plants, such as knowledge of the crop to be planted, sowing time, area selection, periods critical to waterlogging and harvesting time (Vernetti \& Gomes, 2009).

For the maize crop, in Rio Grande do Sul, it is recommended to sow between August and September, so that the flowering coincides with the longest days, as well as the sowing depth, due to the soil temperature and moisture of these areas (Cruz et al., 2006). The critical periods in relation to waterlogging for maize are the initial stages, where only one day with saturated soil is enough to occur the plant death (Embrapa, 2013). For the soybean crop the phenological stages V2, R2, R3 and R4 are significantly affected by waterlogging, reducing grain yield. In addition to the initial growth periods of the crop, which directly affect the establishment of the crop (Schöffel et al., 2001; Wuebker et al., 2001). The intensity in which the episode of flooding affects the growth and development of the plants is conditioned to the time of flooding of the soil, where short occurs of one or two 
days, the plant resists better to the episode of stress, when long, changes occur in the root system, such as death of the main root (Pires et al., 2002; Fante et al., 2010).

\section{Drainage of Lowland Soils to Receive Upland Crops, Increase the Stability of Aggregates and Reduce Crumbling}

Soil preparation in lowland areas is one of the main practices performed for the implantation of upland crops in these areas, in order to correct the terrain surface (Louzada et al., 2008). The drainage is fundamental, in this way it is advisable to carry out practices, such as: planing in order to minimize to the depressions elevations of the terrain and systematization to improve the surface runoff of the water. Thus some systems can be employed, such as planting in ridges, which improves runoff and allows irrigation by furrows, and is used for the implementation of maize, soybean and cotton crops (Elloy). As studies by Marchesan et al. (2013) that report the use of ridges provides greater accumulation of dry mass in the shoot of the soybean.

The area scarification system provides benefits in order to increase soil pore diameters and increase gaseous exchange, as well as increase soil permeability and reduce waterlogging in flat terrains (Klein et al., 2008; Dalla Rosa, 1981).

\section{Improvement of Soil Quality Due to Rotation}

The use of the rotation system provides significant improvements to the soil, by increasing the natural fertility of the soil, by the contribution of carbon and nutrients, also diversifies the income of the farmer, being an alternative capable of increasing productive potential, reduce production costs and the risks of environmental impact (Rego, 2004). Rotation plays an important role in controlling diseases with the breaking of cycles, allowing the cycling of nutrients through different rooting and reducing weed infestation. In the lowland areas rotation is the most efficient method to combat red rice, which is the main irrigated rice weed (Shoenfeld, 2010). The main rotational rainfed crops are maize, soybean, sorghum and some pasture species.

\section{Potentiality of Upland Crops in Lowland Areas (Soybean and Maize)}

The high productivity achieved by the irrigated rice crop, the intense use of the lowland areas, together with the competitive market, awakens in the farmers the search for alternatives that are capable of increasing the productive potential of their areas as well as reducing the costs of production and impacts on the environment to make the system sustainable. In the conditions of RS, the possibility of more intensive and rational use of lowland soils is directly related to the implantation of a crop rotation system, associated to a permanent cover of the soil surface and to efficient drainage and irrigation.

Crop rotation is one of the factors that is linked to the sustainability of agriculture, since often only the use of modern inputs and with built-in high technology does not allow the farm to be viable, in the case of monoculture of irrigated rice. For example, the need to minimize the control of pests, diseases and weeds of rice crop irrigated with chemical products, since in addition to raising costs, there is a risk of contamination of the environment and appearance of resistance of the main diseases that affect the crop, compromising the lowland ecosystem (Faraco et al., 2016).

The diversification and incorporation of new crops, such as soybean and maize, in these areas is an alternative to increase the efficiency of the production system (Emygdio, Rosa, \& Silva, 2015). Rotation and succession of crops stand out as one of the alternatives that are capable of increasing the productive potential of lowland areas intensively cultivated with irrigated rice. However, the difficulty of drainage and the scarcity of species tolerant to water excess conditions represent a major obstacle to adapting these diversified production systems (Menezes et al., 2001).

Among the alternatives presented, soybean (Glycine max) is one of the species with very interesting characteristics for this production system, being distinguished by the nitrogen supply through the biological fixation improving the fertility of these soils, as well as an alternative to increase the income of the farmer, contributing to the sustainability of the system (Schoenfeld, 2010).

Excess water is one of the most restrictive factors in a soybean crop, either by reducing the plant stand or development. Thus, the objective is to remove all the water from the field as soon as possible, and there can be no accumulation of water at the lowest sites (Mundstock et al., 2017). Many studies indicate that soybean is an alternative, due to the tolerance level of some genotypes (Pires et al., 2002; Schöffel et al., 2001; Van Toai et al., 2010).

Even though soybean is an interesting species in the lowland soils production system, Marchezan (2013) states that the decision to invest in a given activity is related to its cost and benefit, thus, the growth of this crop in 
areas where were only intended for rice cultivation can be explained in part because of the prices that are practiced in this crop, and still its high productivity in these areas.

The introduction of maize in rotation with rice aims to diversify income, thus increasing the profitability of the cultivated area and reducing the economic risks of using monoculture (Wander et al., 2010). The same presents itself as an alternative with great potential in the diversification of crops (Pérez, 2013), provided that some precautions are taken and some specific management characteristic of these regions and, due to the facilities they present (topography, continuity and ease of irrigation), could be a real alternative for the increase of maize production in RS, and consequently in Brazil. In addition, maize grown in this environment improves soil conditions, makes use of fallow areas and causes the disease cycle to break (Pires, 2005). In spite of this, the feasibility of establishing the maize crop in hydromorphic soils depends on an efficient drainage system (Emygdio et al., 2015), knowledge of the demands of the crop, such as the appropriate sowing time, efficiency of the drains, whether superficial or subsuperficial, use of more adapted cultivar, choice of area, harvest season (Vernetti \& Gomes, 2009).

Thus, in addition to the introduction of maize in rotation with rice, it contributes to the reduction of weed infestation, it also brings other benefits such as: environmental, by reducing the use of pesticides to control weeds; economic, for providing the farmer profitability with the implantation of a summer crop instead of the land being fallow; and social, due to the reduction of risk compared to monoculture and the increase in the use of labor for the practice of summer crops in place of fallow (SOSBAI, 2014).

\section{Benefits of Soybean Rotation for Irrigated Rice}

In a conceptual way, crop rotation consists of alternating plant species over time, in the same agricultural area, in a planned sequence of cultivation of different crops, preferably with different root systems, such as grasses and legumes, in the winter or summer, where each species develops a positive residual effect on the soil and the environment or the successor crop. In this context, in many regions of the country, soybean is the main crop, and the species is chosen for commercial and economic purposes, with the purpose of generating income (Embrapa, 2017).

In this system, the phytosanitary treatments employed would be different for each harvest, there would be a change in the active ingredients of the products used, which would make it difficult to select organisms resistant to these active principles (Vedelago et al., 2012). In Rio Grande do Sul, lowland soils are used with irrigated rice and extensive livestock, basically. However, the adhesion of the crop rotation and succession system would allow a more intensive use of these areas, as well as modify the production system, being that in the lowland areas rotation is the most efficient method to combat red rice, which is the main irrigated rice weed (Shoenfeld, 2010).

The greater sustainability of the production systems is directly related to the system of crop rotation. One of the main advantages of this system is the reduction of weed infestation, the breakdown of disease cycles and consequently the control of these diseases in addition to the nutrient cycling due to the use of different root systems, optimization of soil use and improvement of soil quality by the increase of organic matter, optimization of the use of machines and labor, diversification of income, increase of productivity and profitability of the crop. In addition, it may result in less need to apply fertilizers, due to the use of previously applied fertilization, and for implanting the direct sowing (Nascente et al., 2014; Marchezan, 2013; Vernetti Júnior et al., 2009).

In the case of rotation soybean and rice, according to IRGA (2017), there are several utilities for the use of soybean in areas where they were exclusively destined for rice. First is to control weeds, especially red rice. Second, it is feasible to cultivate other crops, profitable and in rotation with the rice, and to reduce the incidence of microorganisms that cause diseases that make difficult the cultivation of rice in many areas. Marchezan (1995) and Avila et al. (2000), found a reduction in the amount of red rice in the soil only with the adoption of crop rotation. In addition to the improvement aspects mentioned above, crop rotation with the use of soybean may contribute to the increment of yield of rice grains if grown in succession (Montealegre \& Vargas, 1989; Pauletto et al., 1991).

The option for this system of rotation with soybean brings a gain of productivity in $20 \mathrm{bags} \mathrm{ha}^{-1}$. The increase in yield of rice grains cultivated in succession has also been observed in research in renowned institutes such as IRGA and EMBRAPA. However, the expansion is often limited by the unstable results in yield, with years of production falling due to excess water and others due to lack of water. 


\section{Crop Rotation in Lowland Areas and No-tillage System}

Producing in a sustainable way requires that some measures be adopted, among them the diversification of agricultural activities aimed at economic, ecological and social development of agriculture (Filizadeh et al., 2007; Crusciol \& Soratto, 2009; Castro et al., 2011). This diversification of the plant species used in the environment allows a smaller attack of insects, pathogens, weeds and an increase in crop productivity, obtaining greater stability of the crops against the environmental changes (Yahuza, 2011).

The lowland areas, as well as the upland areas, may present a decrease in organic matter, compaction related to the type of management and surface erosion (Lisboa et al., 2012). The high degradation of the soil reported is due to anthropic action, mainly of the adopted agricultural practices, necessitating alternatives that mitigate the compaction and the destructuring of these soils.

Crop rotation is essential in agricultural production, since the introduction of a legume species may lead to a decrease in the use of nitrogen fertilizer in the next harvest, due to the fact that the legume significantly increases the available nitrogen in the soil (Filizadeh et al., 2007; Nascente et al., 2013).

In the case of no-tillage system in uplands, it is extremely important to add to the system a considerable amount of waste that comes from the soil cover to increase the amount of organic carbon (C), influencing the nitrogen dynamics. However, in the lowland areas the accumulation of residues has positive aspects, mainly in weed control, however, some problems occur mainly in the initial establishment of the crop by the accumulation of organic acids (Camargo et al., 2001).

Among a series of advantages and benefits that direct sowing brings to the crop, there is a highlight for the better control of weeds, better use of the sowing window and more adequate time, favoring water management, the best cost and benefit, better integration of agriculture/livestock, reduction of physical, chemical and biological degradation of the soil, better viability of crop rotation and sustainability of the production system. In addition to the short-term advantages, as mentioned above, after some years of use other advantages such as the improvement of the physical, chemical and biological attributes of the soil are perceived. These benefits are already well proven in highland soils, but in lowland soils, there is little information about the action of the system.

\section{Irrigation (Irrigation by Bathing in Upland Species)}

Despite the above-mentioned benefits provided to the rice production system, the introduction of upland crops in these areas generally encounters high production costs and large market oscillations as constraints. In addition, there are some environmental limitations for upland crops, mainly caused by the characteristics of these soils along with some climatic and cultivation factors (Gollo, 2016).

In the lowland areas of Rio Grande do Sul, a remarkable peculiarity for the upland species in the summer is the low rainfall in the period from December to February. This problem, along with the high evaporative demand for the atmosphere, mean that the water requirement of these species is not met in order to have profitable productivity for the farmer. Such climatic peculiarities can be determinant for the farmer to use supplementary irrigation, causing the crops to express their full productive potential, obtaining maximum utilization of the inputs (Silva \& Parfitt, 2005).

In this sense, intermittent flood irrigation, also known as bath irrigation, may serve as a tool to minimize these problems. This method presents as advantages the low initial investment due to the fact that it uses the already installed structure in the property with the irrigation of the rice, being able to be used in both systematized and non-systematized crops. Also, this technique relies on the vast experience of rice producers with water management (Embrapa, 2007).

In this method of irrigation, the water enters the crop intermittently until the water depth is formed which is desired by the farmer, withdrawing it immediately after the infiltration time so that the soil remains saturated for a long period. In order to perform this type of irrigation, it is recommended that the water intakes in the frames be independent, using auxiliary channels, and that the size of the frames be adequate, so as to allow irrigation in a short period of time (Bernardo et al., 2006).

\section{References}

Avila, L. A. De, Marchezan, E., Scivittaro, W. B., Porto, M. P., Silva, R. P. Da, \& Villa, S. C. C. (2000). Produção de Milho, soja e sorgo em solo de várzea, com diferentes níveis de adubação de " $P$ " $e$ " $K$ " ( $p$. 480-487, Documentos 80). In Reunião Técnica do Milho, 45, Reunião Anual do Sorgo, Pelotas. Anais... Pelotas: Embrapa Clima Temperado. 
Bailey-Serres, J., \& Colmer, T. D. (2014). Plant tolerance of flooding stress-Recent advances. Plant, Cell and Environment, 37, 2211-2215. https://doi.org/10.1111/pce.12420

Bailey-Serres, J., \& Voesenek, L. A. C. J. (2008). Flooding stress: Acclimations and genetic diversity. Annual Review of Planta Biology, 59(1), 313-339. https://doi.org/10.1146/annurev.arplant.59.032607.092752

Bernardo, S., Soares, A. A., \& Mantovani, E. C. (2006). Manual de irrigação (8th ed., p. 625). Viçosa: Ed. UFV.

Camargo, F. A. O., Zonta, E., \& Santos, G. A. (2001). Aspectos fisiológicos e caracterização de toxidez da ácidos orgânicos voláteis em plantas. Ciência Rural., 31(3), 523-529. https://doi.org/10.1590/S0103-8478200 1000300029

Castro, G. S. A., Crusciol, C. A. C., Negrisoli, E., \& Perim, L. (2011). Sistemas de produção de grãos e incidência de plantas daninhas. Planta Daninha, 29, 1001-1010. https://doi.org/10.1590/S0100-8358201100 0500006

Crusciol, C. A. C., \& Soratto, R. P. (2009). Nitrogen supply for Cover Crops and Effects on Peanut Grown in Succession under a No-till System. Agronomy Journal, 101(1), 41-46. https://doi.org/10.2134/agronj 2008.0054

Cruz, J. C., et al. (2006). Circular Técnica, 77: Manejo do solo para cultura do milho (1st ed., p. 14). Empresa Brasileira de Pesquisa Agropecuária, Sete Lagoas, MG.

Dalla Rosa, A. D. (1981). Práticas mecânicas e culturas na recuperação de características físicas de solos degradados pelo cultivo-solo Santo Angelo (Latossolo Roxo Distrófico) (p. 136, Dissertation (Master in Agronomy), Faculdade de Agronomia, Universidade Federal do Rio Grande do Sul Porto, Alegre).

Embrapa (Empresa Brasileira de Pesquisa Agropecuária). (2007). Sistema sulco/camalhão para irrigação e drenagem em áreas de várzea. Comunicado Técnico 165 Versão Online (1st ed., p. 4). Pelotas, RS.

Embrapa (Empresa Brasileira de Pesquisa Agropecuária). (2013). Indicações técnicas para o cultivo de milho e de sorgo no rio grande do sul—Safras 2013/2014 E 2014/2015. Reunião Técnica Anual de Milho. Pelotas, RS.

Embrapa (Empresa Brasileira de Pesquisa Agropecuária). (2017). Conceitos e Benefícios da Rotação de Cultura.

Emygdio, B. M., Rosa, A. P. S. A., \& Silva, J. J. C. (2015). Cultivo de milho em terras baixas: cultivares BT x convencional. Revista SEEDnews, XIX(4), 2425.

Fante, C. A., Alves, J. D., Goulart, P. F. P., Deuner, S., \& Silveira, N. M. (2010). Respostas fisiológicas em cultivares de soja submetidas ao alagamento em diferentes estádios. Bragantia, 69(2), 253-261. https://doi.org/10.1590/S0006-87052010000200001

Faraco, J. R., Castro, N. M. R., Louzada, J. A., Silva, P. R. F., Schoenfeld, R., Maass, M. B., \& Pagliarini, N. (2016). Rendimento de grãos e eficiência do uso de água da cultura do milho em áreas de cultivo de arroz inundado com diferente manejo de irrigação e drenagem. Irriga, Edição Especial, 274-290. https://doi.org/10.15809/irriga.2016v1n1p274-290

Filizadeh, Y., Rezazadeh, A., \& Younessi, Z. (2007). Effects of Crop Rotation and Tillage Depth on Weed Competition and Yield of Rice in the Paddy Fields of Northern Iran. Journal of Agricultural Science and Technology, 9, 99-105.

Gollo, E. de A. (2016). Sistemas de implantação e irrigação por superfície para o cultivo de milho em áreas de arroz irrigado (Dissertação (Mestrado em Engenharia Agrícola), Centro de Ciências Rurais, Universidade Federal de Santa Maria, Pelotas).

Gomes, A. da S., et al. (2002). Rotação de culturas em áreas de várzea e plantio direto de arroz. Embrapa Clima Temperado.

Gomes, A. S., \& Magalhães Júnior, A. M. (2004). Arroz Irrigado no Sul do Brasil (pp. 75-95). Brasília, DF: Embrapa Informação Tecnológica.

IRGA (Instituto Riograndense do Arroz). (2017). Soja 6000: Manejo para altas produtividades em terra baixas. Porto Alegre: Gráfica e Editora RJR.

Kissmann, K. G. (2007). Plantas infestantes e nocivas (3rd ed.). São Paulo: Basf Brasileira.

Klein, V. A., Vieira, M. L., Durigon, F. F., Massing, J. P., \& Fávero, F. (2008). Porosidade de aeração de um Latossolo Vermelho e rendimento de trigo em plantio direto escarificado. Ciência Rural, 38(2), 365-371. https://doi.org/10.1590/S0103-84782008000200011 
Lamego, F. P., Vidal, R. A., Burgos, N. R., \& Federizzi, L. C. (2009). Resistência cruzada de Bidenssubalternans aos inibidores da cetolactatosintase no Brasil. Weed Res, 49(6), 634-641. https://doi.org/10.1111/j.13653180.2009.00734.x

Lisboa, B. B., Vargas, L. K., \& Silveira, A. O. (2012). Indicadores microbianos de qualidade do solo em diferentes sistemas de manejo. Revista Brasileira de Ciencia do Solo, 36, 33-43. https://doi.org/10.1590/ S0100-06832012000100004

Machado, R. L. T., Turatti, A. L., Machado, A. L. T., Alonço, A. S., \& Reis, Â. V. (1996). Estudo de parâmetros físicos em solo de várzea, antes e após a escarificação. Revista Brasileira de Agrociência, 2(3), 175-178.

Marchesan, E., Aramburu, B. B., Vizzotto, V. R., Oliveira, M. L., Castro, I. A., Tonetto, F., \& Giacomeli, G. (2013). Sistemas de implantação e seus efeitos na resistência mecânica do solo à penetração de raízes e na produtividade de soja em área de várzea. Anais VIII Congresso Brasileiro do Arroz Irrigado, Santa Maria. Avaliando cenários para a produção sustentável de arroz. Santa Maria: UFSM; Porto Alegre: SOSBAI.

Marchesan, et al. (2013). Resposta de sistemas de implantação na resistência mecânica do solo a penetração e na produtividade de soja em área de várzea. Congresso Brasileiro de Arroz Irrigado, VIII, Santa Maria, RS.

Massa, D., \& Krenz, B. (2011). Gerhards, R. A resistência do local-alvo aos herbicidas inibidores da ALS em populações de Aperaspica-venti é conferida por mutações documentadas e previamente desconhecidas. Weed Res, 51(3), 294-303. https://doi.org/10.1111/j.1365-3180.2011.00843.x

Menezes, V. G., Mariot, C. P., Lopes, M. C. B., Silva, P. R. F., \& Teichmann, L. L. (2001). Semeadura direta de genótipos de arroz irrigado em sucessão a espécies de cobertura de inverno. Pesquisa Agropecuária Brasileira, 36(9). https://doi.org/10.1590/S0100-204X2001000900004

Meurer, E. J. (2017). Fundamentos de química do solo (p. 280). Porto Alegre.

Mittler, R. (2002). Oxidative stress, antioxidants and stress tolerance. Trends in Plant Science, 7, 405-410. https://doi.org/10.1016/S1360-1385(02)02312-9

Montealegre F., \& Vargas, J. P. (1989). Efecto de algunaspracticasculturales sobre lapoblación de arroz rojo y losrendimientosdel arroz comercial. Arroz, Bogotá, 38(359).

Müller, E. A., et al. (2015). Capacidade de preparos de solo reduzirem limitações físicas naturais de áreas de várzea para o cultivo de soja.

Mundstock, C. M., et al. (2017). SOJA 6000: Manejo para alta produtividade em terras baixas (p. 68). Porto Alegre: Gráfica e Editora RJR.

Nascente, A. S., Li, Y. C., \& Crusciol, C. A. C. (2013). Cover crops and no-till effects on physical fractions of soil organic matter. Soil and Tillage Research, 130, 52-57. https://doi.org/10.1016/j.still.2013.02.008

Nascente, A. S., Silveira, P. M., \& Wander, A. E. (2014). Viabilidade agroeconômica de rotação de culturas e manejo do solo em áreas irrigadas por aspersão. Revistade Ciencias. Agrárias, 57(1), 72-79. https://doi.org/10.4322/rca.2013.068

Neto, M. B. O., \& Silva, M. S. L. (2011). Gleissolos. Empresa Brasileira de Pesquisa Agropecuária, Brazil.

Pauletto, E. A., Turatti, A. L., Gomes, A., \& Da, S. (1991). Produtividade do arroz irrigado em sistema de cultivo mínimo e em rotação com soja e milho. Reunião da Cultura do Arroz Irrigado. Anais... Camboriú, EMPASC.

Pauletto, E. A., et al. (2004). Física se solos de várzea cultivados com arroz irrigado. In A. S. Gomes, \& A. M. Magalhães Jr. (Eds.), Arroz irrigado no sul do Brasil (pp. 119-141). Brasília, DF: Embrapa Informação Tecnológica.

Pérez, M. (2013). Plantio em terras baixas é a saída para aumentar produção gaúcha de milho e atender demanda.

Pinto, L. F. S., et al. (1999). Caracterização dos solos de várzea. In A. D. S. Gomes, \& E. A. Pauletto (Eds.), Manejo de solo e da água em áreas de várzea (pp. 11-36). Pelotas: Embrapa Clima Temperado.

Pinto, L. F. S., et al. (2004). Solos de várzea do sul do Brasil cultivados com arroz irrigado. In A. S. Gomes \& A. M. Magalhães (Eds.), Arroz irrigado no sul do Brasil (pp. 75-95). Brasília, DF: Embrapa Informação Tecnológica. 
Pinto, L. F. S., Gomes, A. S., Neto, L. A. J., \& Pauletto, E. A. (2006). Solos cultivados com Arroz Irrigado na Região Subtropical: RS e SC. In J. R. Magalhães, A. M. Gomes, A. Da, \& Santos, A. B. (Eds.), Sistema de Cultivo de Arroz Irrigado no Brasil (pp. 59-72). Pelotas, RS: Embrapa Clima Temperado.

Pires, C. (2005). Milho na Várzea. Edição 608. Revista A Granja. Retrieved from http://www.edcentaurus. com.br/materias/granja.php?id $=3419$

Pires, J. L. F., Soprano, E., \& Cassol, B. (2002). Adaptações morfofisiológicas da soja em solo inundado. Pesquisa Agropecuária Brasileira, 37, 41-50. https://doi.org/10.1590/S0100-204X2002000100006

Ramesh, C. M. (2009). Waterlogging-induced increase in sugar mobilization, fermentation, and related gene expression in the roots of mung bean (Vignar adiata). Journal of Plant Physiology, 166, 602-616.

Rego, P. G. (1994). Economia das rotações de cultura em plantio direto. Revista Mensal Batavo, 31, 20-28.

Reichert, J. M., Reinert, J. D., \& Braida, J. A. (2003). Qualidade dos solos e sustentabilidade dos sistemas agrícolas. Ciência \& Ambiente, 27, 29-48.

Santos, H. G., \& Zaroni, M. J. (2011). Planossolos. Empresa Brasileira de Pesquisa Agropecuária, Brazil.

Schoenfeld, R. (2010). Sistemas de rotação arroz e soja em sucessão a plantas de coberturas em planossoloháplico (Dissertation (Master in Soil Science), Universidade Federal de Santa Maria. Santa Maria).

Schoffel, E. T., Saccol, A. V., Manfron, P. A., \& Medeiros, S. L. P. (2001). Excesso hídrico sobre os componentes do rendimento da cultura da soja. Ciência Rural, 31(1). https://doi.org/10.1590/S0103-84782001000100002

Silva, C. A. S., et al. (2007). Comunicado Técnico 165: Sistema sulco/camalhão para irrigação e drenagem em áreas de várzea (1st ed., p. 4). Embrapa, Pelotas, RS.

Silva, C. A. S., \& Parfitt, J. M. B. (2005). Irrigação por Inundação Intermitente para Culturas em Rotação ao Arroz em Áreas de Várzea do Rio Grande do Sul (p. 12). Pelotas: Embrapa Clima Temperado.

SOSBAI (Sociedade Sul-Brasileira de Arroz Irrigado). (2014). Arroz irrigado: Recomendações técnicas da pesquisa para o Sul do Brasil/XXX Reunião Técnica da Cultura do Arroz Irrigado, 06 a 08 de agosto de 2014, Bento Gonçalves, RS, Brasil. Sociedade Sul-Brasileira de Arroz Irrigado, Santa Maria.

Sousa, D. M. G., \& Lobato, E. (2007). Gleissolo Háplico. Empresa Brasileira de Pesquisa Agropecuária, Brazil.

Van Dongen, J. T., Gupta, K. J., Ramirez-Aguilar, S. J., Araujo, W. L., Nunes-Nessi, A., \& Fernie, A. R. (2011). Regulation of respiration in plants: A role for alternative metabolic pathways. Journal of Plant Physiology, 168, 1434-1443. https://doi.org/10.1016/j.jplph.2010.11.004

Van Toai, T. T., Thi, T. C. H., Thi, N. N. H., Nguyen, H. T., Shannon, J. G., \& Rahman, M. A. (2010). Flooding Tolerance of Soybean [Glycine $\max$ (L.) Merr.] Germplasm from Southeast Asia under Field and Screen-House Environments. The Open Agriculture Journal, 4, 38-46. https://doi.org/10.2174/18743315 01004010038

Vedelago, A., et al. (2012). Fertilidade e aptidão de uso dos solos para o cultivo de soja nas regiões arrozeiras do Rio Grande do Sul: Boletim técnico ${ }^{\circ} 12$ (p. 48). Cachoeirinha: Starprodutora.

Vernetti, F. J. J., Gomes, A. S., Schuch, L. O. B. (2009). Sustentabilidade no sistema de rotação e sucessão de culturas em solo de várzea no Sul do Brasil. Ciência Rural, Santa Maria, 39(6), 1708-1714. https://doi.org/10.1590/S0103-84782009005000112

Wander, A. L., Souza, R. Da S., Ricardo, T. R., Silveira, P. M. da. (2010). Viabilidade econômica e risco da rotação e consorciação de cultivos para a integração lavoura-pastagem em condições irrigadas no cerrado brasileiro. Informações Econômicas, 40(5).

Wuebker, E. F., Mullen, R. E., \& Koehler K. (2001). Flooding and Temperature Effects on Soybean Germination. Crop Science, 41, 1857-1861. https://doi.org/10.2135/cropsci2001.1857

Yahuza, I. (2011). Review of some methods of calculating intercrop efficiencies with particular reference to the estimates of intercrop benefits in wheat/faba bean system. International Journal of Bioscience, 1(1), 18-30. 


\section{Copyrights}

Copyright for this article is retained by the author(s), with first publication rights granted to the journal.

This is an open-access article distributed under the terms and conditions of the Creative Commons Attribution license (http://creativecommons.org/licenses/by/4.0/). 